 \\ z Filologii Polskiej i Słowiańskiej
}

\author{
Julia Mazurkiewicz-Sułkowska \\ (Uniwersytet Łódzki)
}

\section{Internacjonalizmy jako źródło ekwonimii w słowiańskiej terminologii technicznej (na materiale polskim, rosyjskim i bułgarskim)}

Zaprezentowane w niniejszym artykule uwagi są częścią projektu pt. Terminologia techniczna $w$ językach słowiańskich, którego celem jest opis terminologii technicznej w językach słowiańskich na przykładzie terminów z zakresu budowy i eksploatacji maszyn w trzech językach, reprezentujących odrębne historycznie słowiańskie wspólnoty językowe (polski - zachodniosłowiański, rosyjski - wschodniosłowiański, bułgarski - południowosłowiański). Podstawę materiałową badań stanowi 3200 pojęć z zakresu budowy i eksploatacji maszyn, którym odpowiada prawie 12000 jednostek terminologicznych (po ok. 4000 terminów dla każdego z badanych języków) ${ }^{1}$.

1 Zarówno kryteria doboru jednostek terminologicznych, jak i stan badań nad współczesną terminologią techniczną wraz z bardzo obszerną bibliografią przedmiotu zawiera monografia Słowiańska terminologia techniczna (na materiale polskim, rosyjskim i bułgarskim) (Mazurkiewicz-Sułkowska, 2014).

This is an Open Access article distributed under the terms of the Creative Commons Attribution 3.0 PL License (creativecommons.org/licenses/by/3.0/pl/), which permits redistribution, commercial and non-commercial, provided that the article is properly cited. () The Author(s) 2015. 
Badania, zgodnie z założeniami współczesnego językoznawstwa, są prowadzone w kierunku od pojęcia, realizowanego przez definicję, do jednostek terminologicznych, realizujących dane pojęcie. W związku z powyższym wszystkie jednostki terminologiczne, odpowiadające jednej definicji, stanowią realizacje językowe jednego pojęcia.

1. Już pierwsze spojrzenie na słowiańską terminologię techniczną pokazuje, że często do leksykalizacji jednego pojęcia używa się kilku jednostek terminologicznych odpowiadających tej samej definicji. W literaturze przedmiotu zjawisko polegające na pełnej zbieżności znaczeniowej kilku terminów jest nazywane ekwonimią. Mimo że jest to sprzeczne z zasadą jednomianowości (por. Mazur, 1961), pary ekwonimów są nie tylko zjawiskiem naturalnym, lecz także zalecanym przez ISO (por. Lukszyn \& Zmarzer, 2006, ss. 38-39). Już wstępne badania słowiańskiej terminologii z zakresu cukrownictwa (por. Mazurkiewicz-Sułkowska, 2013) wykazały, że ekwonimia bardzo często dotyczy par terminologicznych składających się z jednostki rodzimej i internacjonalizmu o tym samym znaczeniu.

Podejście takie jest swego rodzaju kompromisem w sporze dotyczącym wyboru jednostek rodzimych lub zapożyczonych. Za jednostki rodzime uważam tu nie wyłącznie terminy pochodzenia rodzimego, lecz wszystkie jednostki terminologiczne danego języka niebędące internacjonalizmami. Dla potrzeb niniejszego opracowania jednostki takie będą określane mianem terminów narodowych. Odróżnienie to jest szczególnie istotne, gdyż bardzo często terminy techniczne mają pochodzenie obcojęzyczne, lecz nie wszystkie jednostki zapożyczone są internacjonalizmami, czyli terminami funkcjonującymi jednocześnie w kilku językach międzynarodowych. Przykładami par terminologicznych składających się z jednostki tzw. narodowej i internacjonalizmu w językach słowiańskich są poniższe terminy:

\section{Rosyjski:}

чиллер / компрессорная система охлаждения ииркулирующей жидкости, нория / черпаковый подъёмник, изиклон / иентробежный пылеуловитель, конвертор - преобразователь.

\section{Polski:}

chiller / sprężarkowy układ chłodzenia cieczy obiegowej, cyklon / odpylacz odśrodkowy. 


\section{Bułgarski:}

чильр / водоохлаждам агрегат,

ииклон / иентробежен прахоотделител.

Za internacjonalizm uważam tu termin, który występuje w co najmniej dwóch językach międzynarodowych (zazwyczaj dostosowany do wymowy, pisowni i gramatyki języka docelowego) i we wszystkich tych językach wyraża to samo pojęcie (por. Lukszyn \& Zmarzer, 2006, ss. 70-71). Dostosowywanie do norm języków narodowych polega w przypadku omawianych tu terminów na tym, że „W niewielkim stopniu zmienia się ich postać - i w ten sposób, zachowując wspólne rdzenie, stają się one terminami międzynarodowymi” (Stoberski, 1982, ss. 26-27). Nie są jednak internacjonalizmami kalki językowe, będące dosłownym przekładem terminów obcojęzycznych, ponieważ nie spełniają one podstawowego wymagania internacjonalizmów, czyli nie są zrozumiałe dla międzynarodowego środowiska branżowego. W językach wyjściowych internacjonalizmy bardzo często są terminami-metaforami, podczas gdy w językach zapożyczających są to już jednostki wyłącznie należące do leksyki konwencjonalnej, które nie wzbudzają skojarzeń z jednostkami z języka ogólnonarodowego, por. ros. / bg. шнек (niem. Schnecke 'ślimak'). W odróżnieniu od nich kalka językowa (por. pl. ślimak) w języku docelowym pozostaje metaforą i dzięki skojarzeniom ułatwia zrozumienie terminu tak, jak i w języku wyjściowym. Nie jest ona jednak internacjonalizmem, czyli terminem zrozumiałym w środowisku międzynarodowym.

Zwyczajowo internacjonalizmami są nazywane zarówno jednostki utworzone na bazie języków klasycznych, jak i terminy przejęte z języków światowych (obecnie przede wszystkim $\mathrm{z}$ angielskiego, a wcześniej - niemieckiego i francuskiego). O terminach pochodzenia łacińskiego i greckiego już Zenon Klemensiewicz pisał, że są one skutkiem „kulturalnych i cywilizacyjnych związków ze światem szczególnie europejskim. [...] są wygodne i przydatne dzięki przyporządkowanej im jednoznaczności, bo łatwiej znoszą różne zabiegi słowotwórcze jako wytwory sztucznie kombinujące składniki języków już martwych" (Rybicka, 1976, s. 37). O ile internacjonalizmy pochodzenia greckiego i łacińskiego są przyjmowane bez większych oporów, o tyle terminy przyjęte z języków współczesnych muszą „walczyć” z neologizmami o rodzimym źródłosłowie i kalkami, ponieważ każdy leksykon terminologiczny dąży do przestrzegania zasady jednomianowości. Nie da się jednak uniknąć współdziałania języków terminologicznie zabezpieczonych, które wpływa na strukturę ich leksykonów terminologicznych. „Współdziałanie takie, 
w rezultacie którego osiąga się wyższy stopień kompatybilności różnojęzycznych leksykonów, prowadzi do umiędzynarodowienia (= internacjonalizacji) odrębnych systemów terminologicznych, tzn. do ich zharmonizowania pod względem zarówno konceptualnym, jak i formalnym. Harmonizacja Leksykonu terminologicznego oznacza umiędzynarodowienie odpowiedniego repertuaru jednostek terminologicznych w celu ułatwienia komunikacji zawodowej na arenie międzynarodowej” (Lukszyn \& Zmarzer, 2006, ss. 70-71).

Od wielu lat toczy się spór w sprawie wyboru jednostki rodzimej lub internacjonalizmu. Jest to zagadnienie, które od dłuższego czasu wzbudza duże kontrowersje zarówno wśród techników, jak i wśród językoznawców. Do problemu internacjonalizacji terminologii już w roku 1813 odniósł się Jan Śniadecki. Będąc zwolennikiem poprawnej terminologii rodzimej zaznaczał jednocześnie, że „słysząc wyraz zagraniczny każdy dowiaduje się o jego znaczeniu; słysząc zaś źle wynaleziony krajowy, może się domyślać i robić sobie znaczenie fałszywe" (por. Toskański, 1978, ss. 147-148). Witold Doroszewski podkreślał, że „terminologia naukowa powinna mieć charakter międzynarodowy w możliwie najrozleglejszej skali [...] Wznoszenie sztucznych przeszkód między nami a światem nikomu nie przynosi pożytku, a najmniej nam samym, bo nam przede wszystkim powinno zależeć na tym, aby świat nas znał" (Doroszewski, 1950, s. 24). W literaturze od lat podkreśla się właśnie jednoznaczność internacjonalizmów i fakt, że nie wzbudzają one żadnych zbędnych konotacji. Orędownikami oddawania pierwszeństwa wyrazom międzynarodowym są zazwyczaj technicy. Jest to zrozumiałe, gdyż dążą oni do zminimalizowania barier w komunikacji z kolegami z zagranicy. Za pozytywny przykład takiego rozstrzygnięcia służy zazwyczaj terminologia medyczna, która przeciwstawiła się tendencji zamiany terminów międzynarodowych przez wyrazy rodzime i przez to wymiana myśli medycznej jest precyzyjna i szybka.

Bezkrytyczne przyjmowanie internacjonalizmów jest jednak często sprzeczne z normami poprawnościowymi. Na gruncie polszczyzny wyróżniają się tu prace Edwarda Musiała, który jest orędownikiem jednoznacznej i poprawnej terminologii technicznej zgodnej z zasadami poprawnej polszczyzny. W związku z ogromną liczbą neologizmów terminologicznych (zarówno internacjonalizmów, jak i niezgodnych z zasadami polszczyzny kalek) alarmuje on, że „Grozi nam tyle wersji terminów technicznych i definicji, ile jest zainteresowanych komisji normalizacyjnych" (Musiał, 2002, ss. 96-97).

Stosunek opisywanych języków narodowych do internacjonalizacji słownictwa konwencjonalnego różni je między sobą. Zbadany materiał wyraźnie 
pokazuje, że internacjonalizmy są dużo bardziej rozpowszechnione w języku rosyjskim i bułgarskim - język polski cechuje większa frekwencja rodzimej leksyki konwencjonalnej i wstrzemięźliwość, jeśli chodzi o stosowanie zapożyczeń, np.

ros. регулирующий дроссель - pl. przepustnica regulacyjna - bg. pегулиращ, дросел, ros. иентрифуга - pl. wirówka - bg. центрифуга,

ros. шнек - pl. podajnikślimakowy - bg. шнек,

ros. инвертор - pl. falownik - bg. инвертор.

Istnieją jednak jednostki, gdzie to właśnie polski termin ma brzmienie międzynarodowe, a np. rosyjski - nie, por. ros. охладитель с псевдоожиженным слоем i pl. chłodziarka fluidalna. Nie zmienia to jednak faktu, że polszczyzna ma najmniejsze nasycenie formami internacjonalnymi.

Taką samą tendencję można zaobserwować również w słownictwie naturalnym badanych języków (por. Satoła-Staśkowiak, 2013). Prace magisterskie przygotowane w Katedrze Slawistyki Południowej UŁ pod kierunkiem Małgorzaty Korytkowskiej, np. praca Klaudii Ocimek pt. Najnowsze neologizmy angielskiego pochodzenia na bułgarskich i polskich forach internetowych, potwierdzają dużo większą skłonność współczesnego języka bułgarskiego do zapożyczania leksemów angielskich.

Klasa internacjonalizmów jest częścią większej klasy jednostek terminologicznych pochodzenia obcego. Nie można jednak, co podkreślono już wcześniej, tych dwóch klas utożsamiać. Tak na przykład bułgarskie jednostki terminologiczne pochodzenia rosyjskiego, np. тарелка, вилка, червяк, oraz pochodzenia tureckiego, nр. менгеме, тезгях, кальф, каиш, nie są w terminologii bułgarskiej ani internacjonalizmami, ani terminami-metaforami (jak w językach wyjściowych). Można je więc zaliczyć do klasy terminów narodowych pochodzenia obcego.

2. W celu prześledzenia rozpowszechnienia zjawiska ekwonimii typu „termin narodowy / internacjonalizm” przeprowadzono analizę dla trzech objętych badaniem języków. Uwzględniono przy tym podział na internacjonalizację pełną i internacjonalizację niepełną (por. Гринев-Гриневич, 2008). Pierwsza polega na pełnej zbieżności fonetycznej całej jednostki terminologicznej (np. chiller). Z niepełną (hybrydową) internacjonalizacją mamy do czynienia w przypadku jednostek terminologicznych, w których jeden lub dwa człony są internacjonalizmami, pozostałe zaś - nie (np. amortyzator hydrauliczno-powietrzny). 
2.1. Ekwonimia wynikająca $\mathrm{z}$ jednoczesnego funkcjonowania internacjonalizmu i terminu narodowego w języku polskim.

Terminologię polską cechuje stosunkowo niska liczebność par składających się z jednostki narodowej (czasami internacjonalizmu częściowego) i internacjonalizmu pełnego (którego wszystkie człony są oparte na źródłosłowie międzynarodowym). Terminy takie stanowią zaledwie około 8\% wszystkich par ekwonimów wynikających $\mathrm{z}$ jednoczesnego funkcjonowania jednostki narodowej i internacjonalizmu (pełnego lub częściowego). Przykładami tego typu par mogą być:

bęben do siarczkowania - barat,

sprężarkowy układ chłodzenia cieczy obiegowej - chiller,

izolacja dźwiękowa - izolacja akustyczna,

izolacja cieplna - izolacja termiczna,

odpylacz odśrodkowy - cyklon,

separator powietrzny - separator pneumatyczny.

Zdecydowaną większość (ponad 90\%) stanowią pary składające się z jednostki narodowej i częściowego internacjonalizmu, por.

krzywka sercowa - krzywka kardioidalna,

topatka śrubowa - łopatka helikoidalna,

odporność cieplna, odporność na grzanie się - odporność termiczna,

podkładka sprężynująca, podkładka sprężysta - podkładka Grovera,

połązenie szczelne - połączenie hermetyczne,

przegub krzyżakowy - przegub Cardana,

prędkość bezwzględna - prędkość absolutna,

próba szczelności - próba hydrauliczna,

przenośnik powietrzny - przenośnik pneumatyczny,

ruch nieokreślony - ruch aperiodyczny,

sito wstrzasowe - sito wibracyjne,

sprzeganie samoczynne - sprzeganie automatyczne,

suszarka drganiowa - suszarka wibracyjna,

uszczelnienie wodne - uszczelnienie hydrauliczne,

wpust czótenkowy - wpust Woodruffa,

wysokość obliczeniowa - wysokość nominalna.

2.2. Ekwonimia wynikająca $\mathrm{z}$ jednoczesnego funkcjonowania internacjonalizmu i terminu narodowego w języku rosyjskim. 
Julia Mazurkiewicz-Sułkowska Internacjonalizmy jako źródło ekwonimii w słowiańskiej...

Połowę rosyjskich par ekwonimów składających się z jednostki narodowej i internacjonalizmu tworzą pary, w skład których wchodzi internacjonalizm pełny. Przykładami tego typu par mogą być:

жидкостно-воздушный амортизатор - гидропневматический амортизатор, компрессорная система охлаждения ииркулирующей жидкости - чиллер, иентробежный фильтр - изилон, водньй фильтр, водяной фильтр - гидрофильтр, звуковая изоляция, звукоизоляция - акустическая изоляция, тепловая изоляция, теплоизоляция - термическая изоляция, термоизоляиия, влагоизоляция - гидроизоляция, переходной фланеи - фитинг, водяная рубашка - ватержакет, счётчик оборотов - тахометр, натянной ролик - теникс, смазочная подушка, масляная подушка, смазочная щётка - польстер, струйный насос - эжектор, инжектор, конвейер с погружёнными скребками - редлер, роликовый транспортёр, роликовый конвейер - рольганг, многоступенчатый компрессор - компаунд-компрессор, компрессор-компаунд, универсальные клещи, универсальные плоскогуби,ы, комбинированные плоскогубць - пассатижи,

скальчатый поршень - плунжерньй поршень - плунжер,

разделяющая центрифуга - сепарирующая иентрифуга.

Czasami w rosyjskiej terminologii dla leksykalizacji jednego pojęcia są używane równolegle: jednostka narodowa, częściowy internacjonalizm i internacjonalizm pełny, np.

боковое биение - радиальное биение - маги,

ящичный подаватель, черпаковый подъемник, черпаковый питатель - черпаковая нория - нория,

винтовой питатель, червячный питатель - питательный щнек, инековый питатель - шнек,

муфта трения - фрикиионная муфта - фрикцион.

Około połowy rosyjskich par ekwonimów, dotyczących omawianego zagadnienia, stanowią pary wynikające $\mathrm{z}$ istnienia terminu narodowego i częściowego internacjonalizmu, np.

распределительный барабан - барабан-сепаратор, сердиевидный кулачок - кардиоидный кулачок, 
Julia Mazurkiewicz-Sułkowska Internacjonalizmy jako źródło ekwonimii w słowiańskiej...

теплостойкость, нагревостойкость - термическая стойкость, термостойкость,

звеньевой ремень - марнирныци ремень,

теплоизоляционный кожух - термоизоляционный кожух,

паровая подушка - паровой бубер,

уравнительное соединение - эквипотенииальное соединение,

вращзательный насос - роторный насос,

иентробежныцй насос - радиальньй насос,

поверхность трения - фрикиионная поверхность,

понижающая передача - редукторная передача,

винтовое движение - геликоидальное движение,

возвратное движение, возвратный ход - реверсивное движение, реверсивный ход, промежуточная втулка, распорная втулка - дистанционная втулка, вильчатый ползун, закрытыьй ползун - вилкообразныци крейијкопб, воздушный выключатель - пневматический выключатель, ёлочный зуб, угловой зуб - чевронный зуб, водохранилище-охладитель - холодильный резервуар, насадка распьлителя - пульверизирующий насадок.

2.3. Ekwonimia wynikająca $\mathrm{z}$ jednoczesnego funkcjonowania internacjonalizmu i terminu narodowego w języku bułgarskim.

W języku bułgarskim większość tworzą pojęcia leksykalizowane jednocześnie poprzez narodową jednostkę terminologiczną (ew. internacjonalizm częściowy) i internacjonalizm pełny. Klasa ta stanowi prawie $70 \%$ wszystkich par ekwonimów, w skład których wchodzą terminy międzynarodowe. por.

водоохлаждаш агрегат - чильр,

загребвач - грайбер,

дълбачна машина, вертикален струг - щос-машина (щосмашина), иентробежен филтьр - изилон-филтьр, ииклон филтьр, плосък филтьр - планфилтьр, погльщащ, филтьр - абсорбционен филтьр, звукова изолация, противошумна изолачия, звукоизолаиия - акустична изолация,

топлинна изолация, топлоизолация - термична изолация, термоизолачия, противовлажна изолачия - хидроизолачия,

преходен фоанеи - фитинг,

чашкова мелница, бугун - колерганг, 
Julia Mazurkiewicz-Sułkowska Internacjonalizmy jako źródło ekwonimii w słowiańskiej...

брояч на обороти, оборотомер - тахометьр,

пружинна шайба - гроверова шайба, федершайба,

водач, водило - кондуктор,

конвейер с потопени гребла - редлер,

ролков транспортьор - ролганг,

напречна греда - траверса,

редуктор на налягане - редуцииввенти,

редуктор на оборотите - демултипликатор,

автоматична масльонка - лубрикатор,

маслена преса - гресьорка,

струйна помпа - ежектор,

пробивна мачина, пробивен чук - перфоратор,

вретено - шпиндел,

стойка - конзола,

воден акумулатор - хидравличен акумулатор, хидроакумулатор.

Podobnie jak w terminologii rosyjskiej, czasami dla leksykalizacji jednego pojęcia są używane równolegle: jednostka narodowa, częściowy internacjonalizm i internacjonalizm pełny, np.

кофбчен питател, кофичков подавач, кофов подавач - кофбчен елеватор, кофов транспортьор - нория;

винтов питател, винтов подавач, червячен питател, червячен подавачзахранваш шнек, шнеков подавач, шнеков питател - шнек.

Zaledwie ok. 30\% bułgarskich par ekwonimów (dotyczących omawianego zagadnienia) stanowią pary wynikające z istnienia terminu narodowego i częściowego internacjonalizmu, np.

сушилня с псевдокипящ слой - сушилня с флуидизиран слой, зббно колело със стрелковидни збби - шевронно зббно колело, пластинчата верига - Галова верига, шарнирна верига, основна плоча - фундаментна плоча, водещза плоча - кондукторна плоча, подвижен капак - шарнирен капак, пльтно съединение - херметично съединение, въртящо се сито - ротационно сито, триеш съединител - фрикционен съединител, пльзгач - подвижна траверса, вгртящо се бутало - ротационно бутало, 
Julia Mazurkiewicz-Sułkowska Internacjonalizmy jako źródło ekwonimii w słowiańskiej...

захващащо устройство, захващащо съоръжение - грайберно устройство, центробежно работно колело - радиално работно колело,

въздушен прекъсвач, въздушен изключвател - пневматичен прекъсвач,

пневматичен изключвател,

стреловиден зъб - шевронен збб,

погльщаща способност - абсорбционна способност.

3. Z przedstawionego materiału wynika, że we wszystkich badanych językach jednym $\mathrm{z}$ podstawowych źródeł ekwonimii jest współistnienie terminów narodowych i internacjonalizmów. Przeprowadzona analiza jednak wskazuje na wyraźne różnice w zakresie dystrybucji tego zjawiska. Polska terminologia używa jednostek międzynarodowych zazwyczaj jako części składowej terminów analitycznych. Bułgarski system terminologiczny sytuuje się na przeciwległym biegunie, gdyż, korzystając z jednostek o zasięgu międzynarodowym, zapożycza zazwyczaj całą jednostkę i ma najwyższe nasycenie internacjonalizmami pełnymi. Poniższa tabela pokazuje skalę zjawiska:

\begin{tabular}{|l|c|}
\hline \multicolumn{1}{|c|}{ Język } & $\begin{array}{c}\text { Pary ekwonimów zawierające } \\
\text { internacjonalizmy pełne }\end{array}$ \\
\hline polski & $10 \%$ \\
\hline rosyjski & $50 \%$ \\
\hline bułgarski & $70 \%$ \\
\hline
\end{tabular}

Porównując występowanie omawianego zjawiska w poszczególnych językach, można zaobserwować, że dotyczy ono w znacznej mierze tych samych pojęć w trzech badanych językach. Różnica polega jednak na tym, że rosyjskie i bułgarskie pary ekwonimów bardzo często mają strukturę ,internacjonalizm częściowy / internacjonalizm pełny", natomiast w polskim przypadki takie są dużo rzadsze, a w skład pary ekwonimów wchodzi zazwyczaj jednostka narodowa i częściowy internacjonalizm, por.

\section{Bułgarskie:}

конвейер с потопени гребла - редлер,

разделителна иентрофуга - сепарираща иентрофуга,

плосък филтьр - планфилтьр,

редуктор на налягане - редуциирвентил,

редуктор на оборотите - демултипликатор,

въздушен сепаратор - пневматичен сепаратор, автоматична масльонка - лубрикатор. 
Julia Mazurkiewicz-Sułkowska Internacjonalizmy jako źródło ekwonimii w słowiańskiej...

\section{Rosyjskie:}

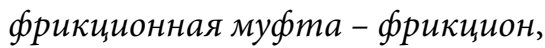

радиальное биение - маги,

конвейер с погружёнными скребками - редлер,

разделяющая иентрифуга - сепарирующая центрифуга.

\section{Polskie:}

podkładka kształtowa - podkładka profilowa,

powierzchnia wyjściowa - powierzchnia bazująca,

ruch nieokreślony - ruch aperiodyczny,

stożek środkujacy - stożek centrujący,

suszarka drganiowa - suszarka wibracyjna,

wpust czólenkowy - wpust Woodruffa.

Powyższe stwierdzenie podkreśla jedynie różnice w zakresie częstotliwości występowania wskazanych typów internacjonalizmów w analizowanych językach, nie wyklucza jednak istnienia rosyjskich i bułgarskich par ekwonimów składających się z jednostki narodowej i częściowego internacjonalizmu, a polskich $-\mathrm{z}$ internacjonalizmu częściowego i pełnego, por.

\section{Rosyjskie:}

ёлочный зуб - чевронный зуб,

сердиевидный кулачок - кардиоидный кулачок,

насадка распылителя - пульверизирующий насадок,

паровая подушка - паровой буфер,

понижающая передача - редукторная передача.

\section{Bułgarskie:}

водеща плоча - кондукторна плоча, подвижен капак-шарнирен капак, захващащо устройство - грайферно устройство, венеи, на работното колело - роторен венеи, укрепващ бгбл - укрепващ, винкел.

\section{Polskie:}

reduktor obiegowy - reduktor satelitowy, separator powietrzny - separator pneumatyczny, pompa obrotowa - pompa rotacyjna. 
Julia Mazurkiewicz-Sułkowska Internacjonalizmy jako źródło ekwonimii w słowiańskiej...

Często dochodzi do sytuacji, gdy polskiej jednostce narodowej (bądź kilku takim jednostkom) odpowiadają rosyjskie i bułgarskie pary typu „termin narodowy / internacjonalizm (pełny lub częściowy)”, por.

licznik obrotów,

счётчик оборотов - тахометр,

брояч на обороти, оборотомер - тахометьр,

mieszarka gniotownika, mieszarka pobocznicowa,

бегунковый смеситель, смешивающие бегуны - коллерганг,

бегунна мелница - колерганг,

pokrywa na zawiasach, pokrywa odchylna,

откидная крышка - шарнирная крышка,

подвижен капак- шарнирен капак.

Stosunkowo nieliczną klasę tworzą pojęcia, leksykalizowane poprzez pary ekwonimów, w skład których we wszystkich analizowanych językach wchodzi internacjonalizm pełny, por.

sprężarkowy układ chłodzenia cieczy obiegowej - chiller,

компрессорная система охлаждения изикулирующей жидкости - чиллер,

водоохлаждам агрегат - чильр,

odpylacz odśrodkowy - cyklon,

центробежный пылеуловитель - ииклон,

центробежен прахоотделител - ииклон,

izolacja dźwiękowa - izolacja akustyczna,

звуковая изоляция, звукоизоляция - акустическая изоляции,

звукова изолация, противошумна изолачия, звукоизолация - акустична изолация.

Klasę, która w trzech językach wykorzystuje jednostki międzynarodowe, tworzą przede wszystkim terminy pochodzenia greckiego i łacińskiego, np. pl. kolumna, ros. колонна, bg. колона (łac. columna), przymiotniki: pl. akustyczny, termiczny, рпеитатусzпу, ros. акустический, термический, пневматический, bg. акустичен, термичен, пневматичен. Należy jednak podkreślić, że te ostatnie we wszystkich badanych językach mają odpowiedniki rodzime, por. pl. dźwiękowy, cieplny, powietrzny, ros. звуковой, тепловой, воздушный, bg. звуков, топлинен, въздушен. 


\section{Bibliografia}

Doroszewski, W. (1950). Kryteria poprawności językowej. Warszawa: Państwowe Zakłady Wydawnictw Szkolnych.

Lukszyn, J. \& Zmarzer, W. (2006). Teoretyczne podstawy terminologii. Warszawa: Katedra Języków Specjalistycznych Uniwersytetu Warszawskiego.

Mazur, M. (1961). Terminologia techniczna. Warszawa: Wydawnictwa Naukowo-Techniczne.

Mazurkiewicz-Sułkowska, J. (2013). Uwagi dotyczące współczesnej terminologii technicznej w języku polskim, rosyjskim i bułgarskim: na przykładzie terminów z branży cukrowniczej. Rozprawy Komisji Językowej Łódzkiego Towarzystwa Naukowego, 59, 123-133.

Mazurkiewicz-Sułkowska, J. (2014). Słowiańska terminologia techniczna: na materiale polskim, rosyjskim i bułgarskim. Łódź: Wydawnictwo Uniwersytetu Łódzkiego.

Musiał, E. (2002). Najwyższy czas zaprzestać parodiowania normalizacji. Informacje o Normach i Przepisach Elektrycznych, (48), 96-110.

Rybicka, H. (1976). Losy wyrazów obcych w języku polskim. Warszawa: Państwowe Wydawnictwo Naukowe.

Satoła-Staśkowiak, J. (2013). Contemporary contrastive studies of Polish, Bulgarian and Russian neologisms versus Language Corpora. Cognitive Studies/Études cognitives, 13, 143-160.

Stoberski, Z. (1982). Międzynarodowa terminologia naukowa: problemy, postulaty, oczekiwania. Warszawa: Państwowe Wydawnictwo Naukowe.

Toskański, A. T. (1978). O twórczości: piśmiennictwo naukowo-techniczne. Warszawa: Państwowe Wydawnictwo Naukowe.

Гринев-Гриневич, С. В. (2008). Терминоведение. Москва: Издательский центр «Академия».

\section{Bibliography (Transliteration)}

Doroszewski, W. (1950). Kryteria poprawności językowej. Warszawa: Państwowe Zakłady Wydawnictw Szkolnych.

Grinev-Grinevich, S. V. (2008). Terminovedenie. Moskva: Izdatel'skiŭ tsentr «Akademiia».

Lukszyn, J. \& Zmarzer, W. (2006). Teoretyczne podstawy terminologii. Warszawa: Katedra Języków Specjalistycznych Uniwersytetu Warszawskiego.

Mazur, M. (1961). Terminologia techniczna. Warszawa: Wydawnictwa Naukowo-Techniczne.

Mazurkiewicz-Sułkowska, J. (2013). Uwagi dotyczące współczesnej terminologii technicznej w języku polskim, rosyjskim i bułgarskim: na przykładzie terminów z branży cukrowniczej. Rozprawy Komisji Językowej Łódzkiego Towarzystwa Naukowego, 59, 123-133.

Mazurkiewicz-Sułkowska, J. (2014). Słowiańska terminologia techniczna: na materiale polskim, rosyjskim i bułgarskim. Łódź: Wydawnictwo Uniwersytetu Łódzkiego. 
Julia Mazurkiewicz-Sułkowska Internacjonalizmy jako źródło ekwonimii w słowiańskiej...

Musiał, E. (2002). Najwyższy czas zaprzestać parodiowania normalizacji. Informacje o Normach i Przepisach Elektrycznych, (48), 96-110.

Rybicka, H. (1976). Losy wyrazów obcych w języku polskim. Warszawa: Państwowe Wydawnictwo Naukowe.

Satoła-Staśkowiak, J. (2013). Contemporary contrastive studies of Polish, Bulgarian and Russian neologisms versus Language Corpora. Cognitive Studies/Études cognitives, 13, 143-160.

Stoberski, Z. (1982). Międzynarodowa terminologia naukowa: problemy, postulaty, oczekiwania. Warszawa: Państwowe Wydawnictwo Naukowe.

Toskański, A. T. (1978). O twórczości: piśmiennictwo naukowo-techniczne. Warszawa: Państwowe Wydawnictwo Naukowe.

\section{Internationalisms as a source of equonymy in Slavic technical terminology (on the basis of Polish, Russian and Bulgarian material)}

\section{Summary}

The article presents one of the main sources of Slavic synonymy in technical terms - the phenomenon of internationalization. On the basis of a comprehensive set of Polish, Russian and Bulgarian terms of the range of machinery (construction and operation) it was found that Polish terminology uses international units primarily as a component of analytic terms, while the Russian and Bulgarian usually borrow the entire terminological unit and less often use a parallel native term. 


\section{Internacjonalizmy jako źródło ekwonimii w słowiańskiej terminologii technicznej (na materiale polskim, rosyjskim i bułgarskim)}

\section{Streszczenie}

W artykule przedstawiono jedno z głównych źródeł ekwonimii w słowiańskiej terminologii technicznej - zjawisko internacjonalizacji. Na podstawie analizy obszernego zbioru polskich, rosyjskich i bułgarskich terminów z zakresu budowy i eksploatacji maszyn ustalono, że polska terminologia używa jednostek międzynarodowych przede wszystkim jako części składowej terminów analitycznych, zaś rosyjski i bułgarski systemy terminologiczne zapożyczają zazwyczaj całą jednostkę terminologiczną i rzadziej używają równolegle terminu rodzimego.

Keywords: terminology; technical terminology; Slavic terminology; internationalism; equonym

Słowa kluczowe: terminologia; terminologia techniczna; słowiańska terminologia; internacjonalizm; ekwonim

\footnotetext{
Julia Mazurkiewicz-Sułkowska, University of Łódź

Correspondence: juliamaz100@yahoo.com

This work was supported by a core funding for statutory activities from the Polish Ministry of Science and Higher Education.

Competing interests: the author declares that she has no competing interests.
} 